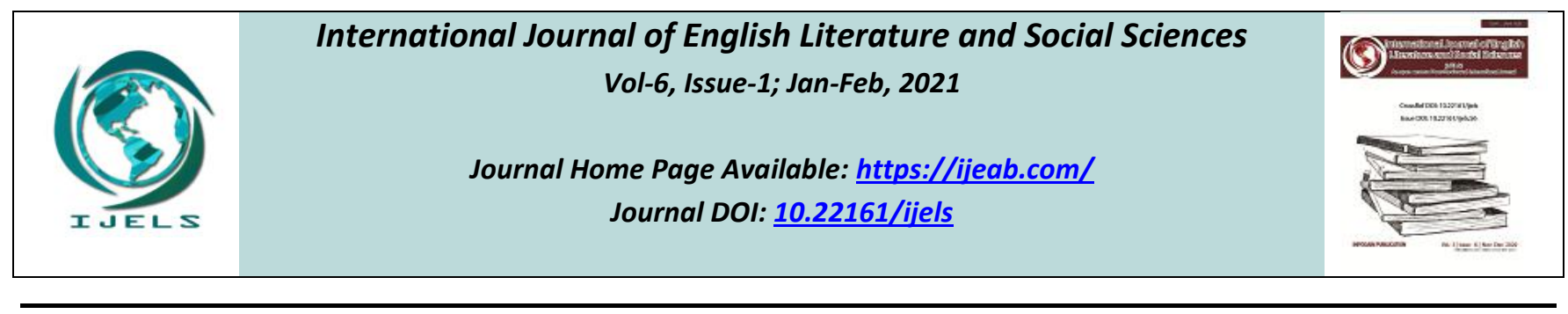

\title{
The Messiah of the Poor: Valjean's Eventful Journey from Hell to Emancipation
}

\author{
Dr. Vivek Chauhan
}

Department of English, Sri Sathya Sai Institute of Higher Learning, Bangalore, India

Received: 03 Nov 2020; Received in revised form: 05 Jan 2021; Accepted: 11 Jan 2021; Available online: 20 Jan 2021 (C)2021 The Author(s). Published by Infogain Publication. This is an open access article under the CC BY license (https://creativecommons.org/licenses/by/4.0/).

\begin{abstract}
The present study brings into focus the character Jean Valjean as an individual who succumbs to adverse circumstances becoming a criminal in the eyes of law. The study analyses him as an individual who faces hell as a convict and ultimately finds redemption from sin through the benevolent interference of the bishop who buys his soul with silver and gives it to God. Finally, Valjean metamorphoses into a kind and sympathetic individual who serves the poor of society; and is ultimately raised to the position of Mayor of Montreuil, remembered by the poor as their Messiah.
\end{abstract}

Keywords - Victor Hugo, Les Misérables, Jean Valjean, Montreuil-sur-mer, Messiah, Bishop.

\section{INTRODUCTION}

Victor Marie Hugo ${ }^{1}$, one of the most renowned poets of France; and by far the greatest genius of his times, wrote one of the greatest epic novels Les Miserables ${ }^{2}$ that won him instant fame. This work was translated into several languages and it inspired many books and screen adaptations ${ }^{3}$. The work was immensely appreciated on account of the fact that it contained characters that were drawn from the middle and the poor class of French society reflecting their desires and aspirations.

\section{THE UNJUST PUNISHMENT}

Garrotto (2008) says, "In Les Miserables, particularly in the life of protagonist Valjean ${ }^{4}$, Victor Hugo drew a map for human living that, if followed, would create a more just, rational, and beautiful world than most human beings live in today." (p.12-13) The hero of this work is Jean Valjean, a poor woodcutter, who, when he is unable to find work in winter; takes to the streets and steals a loaf of bread from a baker to feed his starving sister and her small child. For this little theft of his society punishes him for a period of 19 years during which he metamorphoses into a strong limbed, aggressive and vengeful being. Valjean, who has been starved and tortured in the prison for long, loses patience with the law; and one fine night makes his escape, braving all the difficulties that impede his way to freedom.

\section{THE KIND BISHOP}

At this point we are tempted to believe that Valjean is emancipated. Yes, to a certain extent he is, because he is physically free now and he can go anywhere till he is caught again.

But the question that troubles us is whether he is really free. His body now enjoys huge expanses of physical freedom. But what about his mind? Is Valjean really happy? The answer is a big no. Valjean, the convict, who escapes the prison, is a man of great confusion. His immediate wants are only food and shelter for the night.

Equipped with a yellow passport, he is unable to find even food and shelter wherever he goes. Most of the gentry even shut their doors in his face when they observe his beastly look. Extremely hungry and tired; and with the guidance of an old woman, he goes to a little cottage and knocks. Soon the door is thrown open and a voice says, 'Come in ! What do you want, Dear brother ?' Valjean is taken aback by such an unexpected and warm reception. He enters, imagining that it is an inn and asks of the old 
man if food and shelter would be available for the night. The old man informs him that he is a bishop ${ }^{5}$ and that Valjean was welcome to be seated and that food would be served to him; and that he could also shelter himself there for the night. In this manner the bishop entertains the wild convict despite the opposition he meets from his sister who is ill at ease observing the ferocious appearance of the felon. Valjean , on account of the compassionate nature of the bishop, is allowed to sleep in the cottage that night. In the middle of the night, Valjean, who had been served food in the silverware, tiptoes to the cupboard where the silver is; takes down all the silverware and thrusts them in his sack, jumps out from the window and makes his escape.

Paying with evil for the good done to him, Valjean cannot be held responsible for his actions at this juncture of the story. The unjust treatment meted out to him for stealing a loaf of bread resulted in his heart becoming vengeful against all who are a part of society. Naturally enough, the bishop is also a part of the same society and the mind of Valjean is so clouded with vengeance against society that he is unable to distinguish right from the wrong. He has a feeling of animal satisfaction when he inflicts pain on people after escaping from the prison.

In the morning Valjean is caught by the gendarmes on account of his suspicious appearance and when his bag is searched the silverware belonging to the bishop is found. On being questioned by them Valjean lies that the silverware was given to him as a gift from the bishop. Unable to believe Valjean, the gendarmes present him to the bishop early morning. They inform the bishop that Valjean stole the silverware and escaped. The bishop then comes forward and informs the gendarmes that he had gifted the silverware to Valjean and that they may leave in peace. The gendarmes then withdraw leaving Valjean dumbfounded and stupefied. Shocked by the unexpected generosity, he enquires of the bishop as to why had he done such a thing. The bishop who is ever tranquil replies with grace, "Jean Valjean, my brother, you no longer belong to what is evil but to what is good. I have bought your soul to save it from black thoughts and the spirit of perdition, and I give it to God." (Hugo ,2012,p.111)

\section{THE SUBTLE TRANSFORMATION}

Society unjustly punishes Valjean for 19 years just for stealing a loaf of bread and the Bishop redeems the life of the poor convict and transforms him into a worthy human. Robinson (1921) observes "Jean Valjean is a good man, on whom twenty years of a convict prison have branded an indelible scar; they did nothing to redeem his soul, which he owed to the hazard of a twenty hours' contact with a real saint, M. Myriel, Bishop of Digne."(p.204)

It is at this juncture that the transformation of Valjean takes place slowly but surely. Initially, however, Valjean who has mixed feelings; does not know whether to laugh or cry. The pull of the past is so strong that he frequently feels like relapsing into his sinful and vengeful ways of the past. His mind does not allow him even a bit of the balmy repose that he needs. "His state of mind was physically exhausting. He perceived with dismay that the kind of dreadful calm instilled in him by injustice and misfortune had begun to crumble." ( Hugo,2012,p.112) At this time of his tumultuous existence we are reminded of Milton's Samson ${ }^{6}$ who suffers extreme mental agony on account of his past actions and his present state. The thoughts of Valjean too are like, "hornets armed, no sooner found alone, But rush upon me thronging,..." (Milton,1890,p.117)

The touching scene involving the boy PetitGervais $^{7}$ was the last straw that burnt away the sinful past of Valjean. Having been unjust to the boy, he repented like he had never done before in life. Wanting to break away from the past he called out to the boy whose silver coin he had just pressed under his foot; and unable to find him in order to restore his silver coin, Valjean was filled with an agonising remorse and "His heart overflowed and he wept for the first time in 19 years". ( Hugo ,2012,p.115)

The escape from hell and the entry into heaven is an extremely gradual process; and a mind that has been misunderstood; the soul that has undergone limitless agony on account of the injustice it has suffered at the hands of society needs time to transform even under benevolent influences. The same night Valjean had been observed in the attitude of prayer, kneeling before the cottage of the bishop. This act of his comes to the readers as a confirmation of his transformation to a man of goodness.

\section{THE MAN OF ACTION, NOT OF WORDS}

Valjean had now assumed a new name Madeleine ${ }^{8}$ and under this appellation he performed acts of service that helped him obliterate his ignominious past. In this context his offices at the town of Montreuil-sur-mer ${ }^{9}$ were unsurpassed by any individual before him, be it as a private citizen or a public servant. As a dutiful citizen and a man of a sensitive nature he observed around him filth and poverty; and being himself a victim to penury could realize the state of want and starvation people around him suffered. The wages paid at the factory were miserably low that people with large families could hardly make their both ends meet. It is at this juncture that a great idea struck 
him;and this created a revolution in Montreuil-sur-mer; and by and large alleviated the poverty of the working class and particularly the daily wage earners who were employed in the manufacture of "English jet beads" (Hugo 2012,p.155). The implementation came about in this manner. Madeleine suggested to the proprietors of those factories that to reduce the cost of manufacture of English beads they could substitute "shellac for resin" (Hugo,2012,p.155) Reluctantly though, the idea was taken up and implemented and sure enough it resulted in large profits to the bead manufacturing industry in the town and consequently the wages of the labour went up because the overall manufacturing cost had been cut. In this manner all the working class benefitted on account of M.Madeleine's ingenuity. Another such event was the rescue of persons engulfed in a fire that broke out in the town hall. "Plunging into the flames he had, at the risk of his life, rescued two children whose father, as it turned out, was the captain of Gendarmerie." (Hugo ,2012,p.156) Valjean, who is now Madeleine started to win respect from all quarters,particularly the workers who regarded him as nothing short of their Messiah. In order to generate more employment for the poor of Montreuil-sur-mer Monsieur Madeleine started a new factory ; and two separate workshops were established under it. One was meant exclusively for women and the other for men; since he did not desire gender mixing and the resulting immorality that might arise. With Monsieur Madeleine in charge any vagrant who wished for employment could apply and get a paid job provided he or she was willing to stick to the morals of the place and the strict code of conduct.

Although,as a businessman Monsieur Madeleine earned enormous amounts of profit from the growing bead industry that he had revolutionised with his novel ideas; and his profits gave scope for a general overall being of the working class involved with the industry; yet his benevolence found no bounds as he willing contributed to the supply of credit amounting to 6,35,000 francs to the Banking office at Laffitte. He not only provided more beds to the hospitals in the town; he even built schools where it was necessary and did not leave a stone unturned to insure that the poor of Montreuil-sur-mer did not any longer suffer for lack of infrastructure or opportunities.

\section{THE MAYOR WHO IS THE MESSIAH OF THE POOR}

All the public good that Monsieur Madeleine was undertaking naturally became a talk of the town. People wondered why a stranger like Monsieur Madeleine was doing so much good; some, who were jealous of his growing reputation, also thought that he was perhaps after a political position. His growing fame reached even the King's notice who decided to appoint Monsieur Madeleine the Mayor of Montreuil-sur-mer. Initially Monsieur Madeleine refused the offer;but later, as the pressure mounted from several sides he was compelled to give in to accept the mayor's post; and the singular incident that ultimately convinced him of final acceptance of the position was on account of what an old woman shouted out to him from her doorway, "A good mayor is a useful person. How can you hold back when you have the chance to do good?"(Hugo,2012,p.159)

The old woman's words turned out to be prophetic since Monsieur Madeleine who had now become Monsieur Le Maire continued to do the benevolent deeds that he had begun. Monsieur Le Maire became the saviour of the people of Montreuil-sur-mer . After becoming the Mayor, Monsieur Madeleine had performed such a Herculean task that he immediately rose to the place of a Messiah. The incident that brought out with a great force the total selflessness of Monsieur Madeleine was when one fine morning he was walking through one of the unpaved alleys of the town. His attention was drawn to a crowd of people who were gathered around an individual who had been caught under his loaded cart that had collapsed when the horse died. On enquiry, Monsieur came to know that the person in question was Fauchelevent, who, after losses in business , had become a cart carrier. Fauchelevent had been trapped under the cart after his horse had died, making the loaded cart to sink under the weight.Moment by moment, the old man's ribs were getting crushed. No one tried to help him because the cart itself was so heavy and to extricate a man from below the cart would mean a herculean task. Initially, Monsieur allured the people by offering money to any strong man who went under the cart and heaved it upwards. No one dared to attempt it since it seemed an impossible task. Inspector Javert who was watching said that back at the Toulon prison there was only one person strong enough to lift the heavy weight and that was Valjean. For a time Monsieur's heart pounded as his gaze met Javert's. No one came forth to rescue the groaning man whose ribs would have been crushed in a few minutes more. At this point Monsieur Madeleine went under the cart despite remonstrances from people around that Monsieur would be hurt. Initially nothing seemed to happen and people were afraid for the life of the Mayor. Monsieur made one final effort of his strength and the cart came up slowly; and with the help of all the bystanders Fauchelevent was rescued. Fauchelevent fell at the feet of the mayor and thanked him profusely for having saved his life. Thus we come to realize that Monsieur Madeleine was not just a great and successful businessman; but a 
good human being who turns out to be a Messiah for the poor and oppressed people of Montreuil-sur-mer.

\section{CONCLUSION}

Monsieur Madeleine is the transformed Valjean and this metamorphosis he owes to the bishop who was not less than God to him. He himself becomes the Messiah of the poor on account of the goodness instilled in him. The following traits of his personality uplift him to the place of a Messiah:

Seeing God, Jean Valjean does good. Philanthropy is native to him ; gentleness seems his birthright; his voice is low and sweet; his face-the helpless look to it for help ; his eyes are dreamy, like a poet's ; he loves books ; he looks not manufacturer so much as he looks poet ; he passes good on as if it were coin to be handled; he suffers nor complains ; his silence is wide, like that of the still night; he frequently walks alone and in the country.(Quayle,1902,p.31)

\section{NOTES}

1.Victor Marie Hugo (26 February 1802 - 22 May 1885) was a French poet, novelist, and dramatist of the Romantic movement.

2. Les Misérables is a French historical novel by Victor Hugo published in 1862.

3. Books:1872, Gavroche: The Gamin of Paris, translated and adapted by M. C. Pyle.

1922, The Story of "Les Misérables", adapted by Isabel C. Fortey.1935, Jean Val Jean, a condensed retelling by Solomon Cleaver. Films : Les Misérables (1995 film), Les Misérables (1998 film), Les Misérables (2012 film)

4. Jean Valjean is the hero of Victor Hugo's 1862 novel Les Misérables.

5. Bishop Charles-François-Bienvenu Myriel, referred to as Bishop Myriel is a fictional character in Victor Hugo's 1862 novel Les Misérables.

6. Samson Agonistes is a tragic play by John Milton published in 1671

7. Petit-Gervais is an urchin whom Valjean chases away when he is pestering Valjean to return the silver coin.
8.Valjean is also known in the novel as Monsieur Madeleine, Ultime Fauchelevent, Monsieur Leblanc, and Urbain Fabre.

9. The charming walled town of Montreuil is a perfect destination for a weekend away with its beautiful old houses and churches, its imposing ramparts and its

cobbled streets - not to mention a good selection of restaurants and hotels. In fact its origins lie in Roman times when the sea ran up the estuary of the Canche as far as Montreuil.

\section{REFERENCES}

[1] Garrotto, Alfred.J.(2008).The wisdom of Les Miserables : Lessons from the heart of Jean Valjean. Minneapolis, Lulu Press.

[2] Hugo,Victor.(2012).Les Miserables.New York,Penguin Books.

[3] Milton,John.(1890).Paradise Regained and Samson Agonistes.New York,Mershon Co.

[4] Quayle, William.A. (1902).A hero:Jean Valjean.New York:Eaton \& Mains.

[5] Robinson, Agnes Mary Frances. (1921) Victor Hugo. New York:Holt and Company. 